\title{
NITRATE SOURCE DISTRIBUTION IN RIVERS, ESTUARIES AND GROUNDWATER USING A DUAL ISOTOPE APPROACH AND A BAYESIAN ISOTOPE MIXING MODEL
}

\author{
XUE, D. - LI, J. - WANG, Y. - WANG, J. - WANG, Z.* \\ Tianjin Key Laboratory of Water Resources and Environment, Tianjin Normal University, \\ Tianjin 300387, China
}

Tianjin Key Laboratory of Environmental Change and Ecological Restoration, School of Geographic and Environmental Sciences, Tianjin Normal University, Tianjin 300387, China

*Corresponding author

e-mail: wangzhongliang@vip.skleg.cn; phonelfax: +86-222-3766-6256

(Received 15 $5^{\text {th }}$ Jul 2019; accepted $25^{\text {th }}$ Nov 2019)

\begin{abstract}
Identification and quantification of nitrate $\left(\mathrm{NO}_{3}{ }^{-}\right)$sources in rivers, estuaries and shallow groundwater (SG) may help implementation in the water quality control measures. In this study, a dual isotope approach $\left(\delta^{15} \mathrm{~N}-\right.$ and $\left.\delta^{18} \mathrm{O}-\mathrm{NO}_{3}{ }^{-}\right)$and Bayesian isotope mixing model (SIAR) have applied to estimate the proportional contributions of $\mathrm{NO}_{3}{ }^{-}$from precipitation (NP), $\mathrm{NO}_{3}{ }^{-}$fertilizer (NF), ammonia nitrogen $\left(\mathrm{NH}_{4}{ }^{+}\right)$from fertilizer and rain $(\mathrm{NF} \& \mathrm{R})$, soil $\mathrm{N}$ (Soil), and manure and sewage $(\mathrm{M} \& \mathrm{~S})$ for six rivers, two estuaries and SG in a coastal municipality in northern China. The combination of "M\&S" (17$56 \%)$, "Soil" (21-37\%), and "NF\&R (14-25\%)" contributions occupied more than $60 \%$ in total, and were considered as the dominant $\mathrm{NO}_{3}$ " sources for the rivers and estuaries. The mean proportions of "NF" ranged from 6 to $20 \%$ and "NP" ranged from 2 to $11 \%$, respectively. For SG, the mean proportions of "M\&S" (27\%), "Soil" (22\%), and "NF\&R" (21\%) occupied about $70 \%$ in total, while the residual two $\mathrm{NO}_{3}$ - sources occupied about $19 \%$ for "NF" and $11 \%$ for "NP". We suggest that this approach can be easily modified determine $\mathrm{NO}_{3}$ - sources and help to develop better $\mathrm{N}$ management practices in other environments where $\mathrm{NO}_{3}{ }^{-}$is a major $\mathrm{N}$ contributor.
\end{abstract}

Keywords: $\delta^{15} \mathrm{~N}_{-} \mathrm{NO}_{3}{ }^{-}, \delta^{18} \mathrm{O}-\mathrm{NO}_{3}{ }^{-}$, sources identification, SIAR, $\mathrm{N}$ contribution

\section{Introduction}

$\mathrm{NO}_{3}{ }^{-}$contamination in aquatic systems has become a serious environmental problem throughout the world. With the increasing population, extensive agricultural activities and rapid development of urbanization, the high $\mathrm{NO}_{3}{ }^{-}$levels of water impose a serious threat to drinking water and promote eutrophication, hypoxia, loss of biodiversity and habitat destruction both in riverine and coastal ecosystems (Galloway et al., 2003; Li et al., 2013; Umezawa et al., 2008; Villnäs et al., 2013). Monitoring $\mathrm{NO}_{3}{ }^{-}$concentrations alone cannot fully assess the sources and distribution of $\mathrm{NO}_{3}{ }^{-}$inputs in aquatic systems, which are the key factors in protecting water quality and reducing $\mathrm{NO}_{3}{ }^{-}$loadings.

Since $\mathrm{NO}_{3}{ }^{-}$from different sources (fertilizer, manure, human sewage, soil $\mathrm{N}$ and atmospheric deposition) have distinct isotopic compositions, it is possible to identify these different sources using $\mathrm{N}\left(\delta^{15} \mathrm{~N}\right)$ and $\mathrm{O}\left(\delta^{18} \mathrm{O}\right)$ isotopic values (Xue et al., 2012; Wankel et al., 2015). Pardo et al. (2004) successfully used a dual isotope approach $\left(\delta^{15} \mathrm{~N}\right.$ - and $\left.\delta^{18} \mathrm{O}-\mathrm{NO}_{3}{ }^{-}\right)$to identify atmospheric deposition and microbial nitrification as the two main sources of $\mathrm{NO}_{3}{ }^{-}$in stream water at two forested watersheds. Chang et al. (2002) found that $\delta^{15} \mathrm{~N}$ and $\delta^{18} \mathrm{O}$ values of $\mathrm{NO}_{3}{ }^{-}$indicated manure as the predominant source when discharge and $\mathrm{NO}_{3}{ }^{-}$concentrations were low (winter), and soil-derived $\mathrm{NO}_{3}{ }^{-}$as the predominant source when discharge and $\mathrm{NO}_{3}{ }^{-}$concentrations were high 
(spring-summer) in Mississippi River Basin. For the second tributary Pearl River in southern China, Chen et al. (2009) and Jin et al. (2017) pointed out that the $\mathrm{N}$ and O isotopic values fell in the range of nitrification of reduced fertilizer $\mathrm{N}$ in soil zones. Li et al. (2010) found that the $\delta^{15} \mathrm{~N}$ - and $\delta^{18} \mathrm{O}-\mathrm{NO}_{3}{ }^{-}$values of the Yangtze River indicating a main source from urban sewage effluent.

In addition, to reduce $\mathrm{NO}_{3}^{-}$loadings in aquatic systems, it is quite meaningful to quantify the contributions of different $\mathrm{NO}_{3}{ }^{-}$sources. Some researchers, Deutsch et al. (2006) and Yang et al. (2018) also applied $\delta^{15} \mathrm{~N}$ - and $\delta^{18} \mathrm{O}_{-} \mathrm{NO}_{3}{ }^{-}$to quantify $\mathrm{NO}_{3}{ }^{-}$source distribution in water via a mass balance mixing model (Semmens et al., 2013). However, this method is limited to (1) temporal and spatial variability in $\delta^{15} \mathrm{~N}$ - and $\delta^{18} \mathrm{O}-\mathrm{NO}_{3}{ }^{-}$; (2) isotope fractionation by denitrification; and (3) number of sources $>$ number of isotopes + 1 (Moore et al., 2008; Xue et al., 2009). A mixing model for stable isotope analysis called SIAR (stable isotope analysis in R) under a Bayesian framework has been developed to solve source distribution problems (Parnell et al., 2010). The disadvantages of a mass balance mixing model mentioned above are overcome. Xue et al. (2012) successfully applied SIAR to estimate $\mathrm{NO}_{3}{ }^{-}$source distribution of surface waters of Flanders in Belgium. Thereafter, SIAR was also applied to evaluate contributions of $\mathrm{NO}_{3}{ }^{-}$ sources in underground water (Gaouzi et al., 2013; Chen et al., 2015), rivers (Ding et al., 2014) and reservoir (Yang et al., 2013), respectively.

Tianjin is an important coastal municipality located in the Bohai Bay in northern China. An investigation of surface waters of Tianjin (Wang et al., 2009) reported that $\mathrm{NO}_{3}{ }^{-}$concentrations could highly reach up to $10.3 \mathrm{mg} \mathrm{L}^{-1}$ in rivers, and about $8.1 \%$ of agricultural drainages that $\mathrm{NO}_{3}{ }^{-}$concentrations were over $15 \mathrm{mg} \mathrm{L}^{-1}$. Wang et al. (2011) concluded that $\mathrm{NO}_{3}{ }^{-}$was the dominant Dissolved inorganic nitrogen (DIN) species in coastal water of Tianjin, with water quality deteriorating. Thus, it is essential to specify predominant $\mathrm{NO}_{3}{ }^{-}$sources and assess potential $\mathrm{NO}_{3}{ }^{-}$source distribution, which is of great significance to control water contamination and protect coastal ecological system. The aim of this study is to: (1) apply a dual isotope bi-plot approach $\left(\delta^{15} \mathrm{~N}\right.$ - and $\delta^{18} \mathrm{O}$ $\mathrm{NO}_{3}{ }^{-}$) combining with physicochemical properties to identify $\mathrm{NO}_{3}{ }^{-}$sources; and (2) apply the SIAR model to estimate the contributions of potential $\mathrm{NO}_{3}{ }^{-}$sources in rivers, estuaries and shallow groundwater (SG) in Tianjin.

\section{Material and methods}

\section{Study area}

The investigated rivers, estuaries and SG are located in Tianjin, a coastal municipality in northern China (Fig. 1). The study region is mainly influenced by a warm temperate semi-humid monsoon climate with an average annual temperature of 11.4-12.9 ${ }^{\circ} \mathrm{C}$, and the annual precipitation of 520-660 mm (Yue et al., 2010; Wang et al., 2014). The geological structure is complex, and mostly covered by Cenozoic sediments. The terrain is dominated by plains and depressions, with low mountains and hills in the north, and the altitude gradually decreases from north to south. The highest and lowest altitude are $1052 \mathrm{~m}$ and $3.5 \mathrm{~m}$ in the north and southeast, respectively. The total area of Tianjin is $11919.7 \mathrm{~km}^{2}$ and the coastline is about $153.0 \mathrm{~km}$ (Wang et al., 2013).

The six rivers distributed from north to south are Jiyun River (JY River), Chaobaixin River (CB River), Haihe River (HH River), Dagu sewage River (DG River), Duliujian River (DL River), and Ziyaxin River (ZY River), respectively. The properties of the river are shown in Table 1. The northern rivers, the JY River and the CB River flowing 
through a rural area and are characterized by $144 \mathrm{~km}$ and $81 \mathrm{~km}$ in length, $300 \mathrm{~m}$ and $700 \mathrm{~m}$ in width, $7 \mathrm{~m}$ and 5-7 $\mathrm{m}$ in depth, and a watershed area of $2416 \mathrm{~km}^{2}$ and $1387 \mathrm{~km}^{2}$, respectively (Starks et al., 2014; Chen et al., 2000). Precipitation is the main water supply of the JY River so that the runoff seasonally changed. There is an important livestock breeding base in the watershed area of the CB River. Upper reaches are the main water supply of $\mathrm{CB}$ River. The rivers of $\mathrm{HH}$ and DG flow through the urban and industrial area in the middle of the municipality. The DG River is characterized by $71 \mathrm{~km}$ in length, 54-120 $\mathrm{m}$ in width, and a watershed area of $1000 \mathrm{~km}^{2}$, which is an important river channel that holds industrial wastewater and domestic sewage (Guo et al., 2009). The HH River is characterized by $72 \mathrm{~km}$ in length, $100 \mathrm{~m}$ in width, 3-5 $\mathrm{m}$ in depth, and a watershed area of $2066 \mathrm{~km}^{2}$, and water mainly come from the precipitation and upper reaches (Liu et al., 2010). The HH River is separated by a floodgate into two parts: the upstream of the HH River (HHup) flow through the center of the municipality, while the downstream of the HH River (HHdw) flow through the industrial area. The southern rivers DL and ZY flow through the agricultural and industrial area. The DL River is characterized by $70 \mathrm{~km}$ in length, and $400 \mathrm{~m}$ in width (Lai et al., 2001), where the upper reaches is the main water supply of DL River. The ZY River is characterized by $29 \mathrm{~km}$ in length and 100-300 $\mathrm{m}$ in width (Ding et al., 2016), and water mainly come from the precipitation and upper reaches. One of the studied estuaries is the confluence of the JY and the CB River (CJ Estuary) in north, and the design flow is $4640 \mathrm{~m}^{3} / \mathrm{s}$ (Dong et al., 2007). The other is the estuary of the $\mathrm{HH}$ River (HH Estuary) in middle, and the design flow is $800 \mathrm{~m}^{3} / \mathrm{s}$ (Dong et al., 2007).

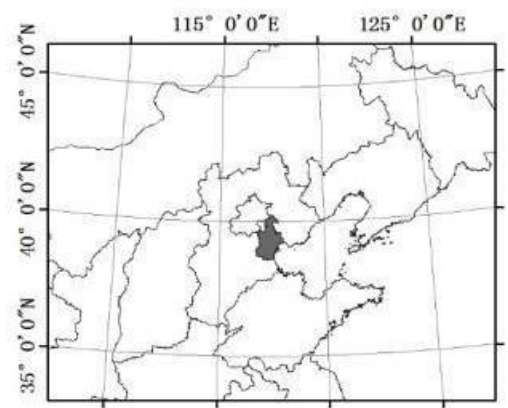

\section{图例}

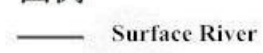

- Surface river sampling point

- Estuary sampling point

* Groundwater sampling point

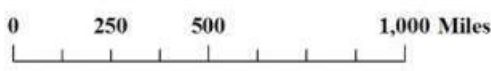

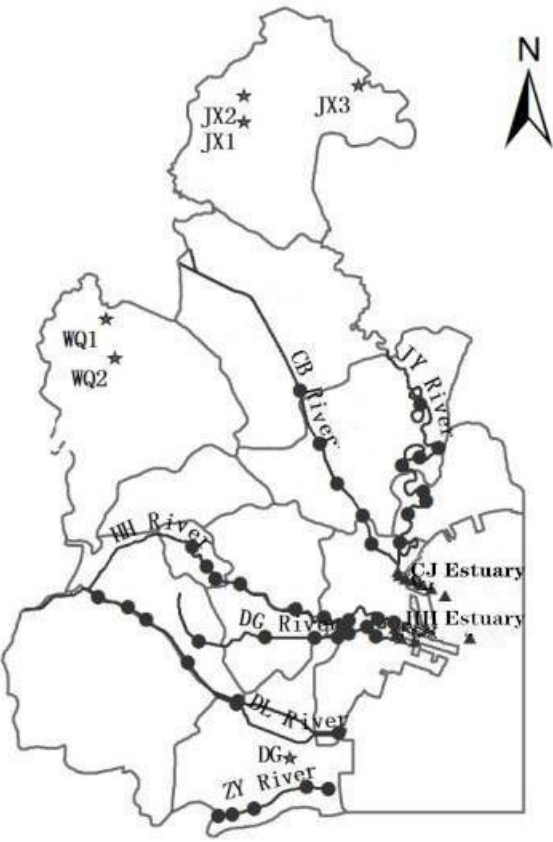

Figure 1. Sampling locations for six rivers, two estuaries and groundwater. $J Y, C B, H H, D G$, $D L$ and $Z Y$ River are the abbreviations of the Jiyun River, the Chaobaixin River, the Haihe River, the Dagu sewage River, the Duliujian River and the Ziyaxin River, respectively. CJ, $H H$ are the abbreviations of the CJ Estuary (co-estuary of the JY and the CB River) and Haihe Estuary, respectively. DG, JX and $W Q$ are the abbreviations of Dagang, Jixian and Wuqing, which are all located in the rural areas of Tianjin. Number represent different sampling locations and-May and-Nov represent samples were collected in mid-May and mid-November during dry and wet periods, respectively 
Table 1. Properties of the rivers and the corresponding estuaries

\begin{tabular}{c|c|c|c|c|c|c|c}
\hline Location & Longitude & Latitude & $\begin{array}{c}\text { Length } \\
(\mathbf{k m})\end{array}$ & $\begin{array}{c}\text { Width } \\
(\mathbf{m})\end{array}$ & $\begin{array}{c}\text { Depth } \\
(\mathbf{m})\end{array}$ & $\begin{array}{c}\text { Drainage } \\
\text { area }\left(\mathbf{k m}^{2}\right)\end{array}$ & $\begin{array}{c}\text { Design } \\
\text { flow }\left(\mathbf{m}^{3} / \mathbf{s}\right)\end{array}$ \\
\hline $\begin{array}{c}\text { JY } \\
\text { River }\end{array}$ & $117.83732^{\circ} \mathrm{E}$ & $39.34846^{\circ} \mathrm{N}$ & 144 & 300 & 7 & 2416 & - \\
\hline $\begin{array}{c}\mathrm{CB} \\
\text { River }\end{array}$ & $117.38531^{\circ} \mathrm{E}$ & $39.60658^{\circ} \mathrm{N}$ & 81 & 700 & $5 \sim 7$ & 1387 & - \\
\hline $\begin{array}{c}\mathrm{CJ} \\
\text { Estuary }\end{array}$ & $117.48532^{\circ} \mathrm{E}$ & $39.03454^{\circ} \mathrm{N}$ & - & - & - & - & 4640 \\
\hline $\begin{array}{c}\mathrm{HH} \\
\text { River }\end{array}$ & $117.19165^{\circ} \mathrm{E}$ & $39.14954^{\circ} \mathrm{N}$ & 72 & 100 & $3 \sim 5$ & 2066 & - \\
\hline $\begin{array}{c}\mathrm{HH} \\
\text { Estuary }\end{array}$ & $117.46202^{\circ} \mathrm{E}$ & $38.57143^{\circ} \mathrm{N}$ & - & - & - & - & 800 \\
\hline $\begin{array}{c}\mathrm{DG} \\
\text { River }\end{array}$ & $117.21497^{\circ} \mathrm{E}$ & $38.95831^{\circ} \mathrm{N}$ & 71 & $54 \sim 120$ & - & 1000 & - \\
\hline $\begin{array}{c}\mathrm{DL} \\
\text { River }\end{array}$ & $116.94644^{\circ} \mathrm{E}$ & $39.04793^{\circ} \mathrm{N}$ & 70 & 400 & - & - & - \\
\hline $\begin{array}{c}\mathrm{ZY} \\
\text { River }\end{array}$ & $117.25816^{\circ} \mathrm{E}$ & $38.60085^{\circ} \mathrm{N}$ & 29 & $100 \sim 300$ & - & - & - \\
\hline
\end{tabular}

The water table of SG in the study area displays different spatial distribution: it is about 10 to $50 \mathrm{~m}$ in the northern piedmont plain, 30 to $80 \mathrm{~m}$ in the middle plain and 2 to $3 \mathrm{~m}$ in the southern littoral plain. Particularly, in recent 20 years, the SG table is steady in northwest and eastern plain of Tianjin, while it goes down yearly in the coastal areas (Wang et al., 2014). Most rivers in this study are artificial, where groundwater cannot compensate because of the relatively low groundwater table level. The flood seasons occurred in July and August, while from May to June and September to next February were dry seasons.

\section{Sampling and analysis}

Samples were collected along the rivers and estuaries in November 2012 and SG samples were sampled in mid-May 2014 and mid-November 2014, during dry and wet periods, respectively. Water samples were taken on a bridge using a bucket serially from upstream downwards for the rivers and on a ship for estuarine water. The bucket was put into the river/estuary water until it reached $\sim 0.5 \mathrm{~m}$ below the surface to sample water. SG is extracted by pumping pump and collected after the water flow is stable (about $5 \mathrm{~min}$ ). Then, the water samples were stored frozen in $1 \mathrm{~L}$ high-density polyethylene (HDPE) bottles for determination of physico-chemical properties and $\delta^{15} \mathrm{~N}$ - and $\delta^{18} \mathrm{O}^{-\mathrm{NO}_{3}}{ }^{-}$. Salinity, $\mathrm{pH}$ and dissolved oxygen (DO) were determined in situ by a portable water quality probe (Thermo Orion, USA). Water samples were filtered through $0.45 \mu \mathrm{m}$ membrane filters and stored at $4{ }^{\circ} \mathrm{C}$ until analysis. $\mathrm{NO}_{3}{ }^{-}$, nitrite $\left(\mathrm{NO}_{2}{ }^{-}\right)$ and $\mathrm{NH}_{4}{ }^{+}$concentrations were analyzed on a continuous flow analyzer (Auto Analyzer 3, Seal, Germany). Chloride $\left(\mathrm{Cl}^{-}\right)$was determined by ion chromatography (ICS-2100, Dionex, USA). The $\delta^{15} \mathrm{~N}$ - and $\delta^{18} \mathrm{O}^{-\mathrm{NO}_{3}}{ }^{-}$values were determined by "Bacterial denitrification method" (Mcilvin et al., 2011; Templer et al., 2011; Xue et al., 2010) in the UC Davis Stable Isotope Facility of California University. 
Stable isotope data of ${ }^{15} \mathrm{~N}$ and ${ }^{18} \mathrm{O}$ are expressed in delta $(\delta)$ units in per mill (\%o) relative to their respective international standards: atmospheric air (AIR) and Vienna standard mean ocean water 2 (VSMOW 2):

$$
\delta_{\text {sample }}(\%)=\left(\frac{R_{\text {sample }}}{R_{\text {standard }}}-1\right) * 1000
$$

where $R_{\text {sample }}$ and $R_{\text {standard }}$ refer to the ${ }^{15} \mathrm{~N} /{ }^{14} \mathrm{~N}$ or ${ }^{18} \mathrm{O} /{ }^{16} \mathrm{O}$ ratio of the sample and standard for $\delta^{15} \mathrm{~N}$ and $\delta^{18} \mathrm{O}$, respectively. The calibration standards are the nitrate salts USGS 32, USGS 34, and USGS 35, supplied by NIST (National Institute of Standards and Technology, Gaithersburg, MD).

\section{Source distribution mixing model (SIAR)}

The contribution proportions of $\mathrm{NO}_{3}{ }^{-}$sources to surface water samples were quantified using the SIAR model (Parnell et al., 2010) as follows:

$$
\begin{gathered}
X_{i j}=\sum_{k=1}^{K} p_{k}\left(s_{j k}+c_{j k}\right)+\varepsilon_{i j} \\
s_{j k} \sim N\left(\mu_{j k}, \omega_{j k}^{2}\right) \\
c_{j k} \sim N\left(\lambda_{j k}, \tau_{j k}^{2}\right) \\
\varepsilon_{i j} \sim N\left(0, \sigma_{j}^{2}\right)
\end{gathered}
$$

where $X_{i j}$ is the observed isotope value $j$ of the sample $i(i=1,2,3, \ldots, N$ and $j=1,2,3, \ldots$, $J) ; s_{j k}$ is the source value $k$ on isotope $j(k=1,2,3, \ldots, K)$ and normally distributed with mean $\mu_{j k}$ and variance $\omega_{j k}^{2} ; c_{j k}$ is the fractionation factor for isotope $j$ on source $k$ and normally distributed with mean $\lambda_{j k}$ and variance $\tau_{j k}^{2} ; \varepsilon_{i j}$ is the residual error which describes additional variation between sample measurements, and it is normally distributed with mean 0 and variance $\sigma_{j}^{2} ; p_{k}$ is the proportion of source $k$ estimated by SIAR.

The fractionation factor, $c_{j k}$ is relevant to denitrification. This process can result in an exponential increase of $\delta^{15} \mathrm{~N}$ - and $\delta^{18} \mathrm{O}_{-} \mathrm{NO}_{3}{ }^{-}$as $\mathrm{NO}_{3}{ }^{-}$concentration decreases. An enrichment of ${ }^{15} \mathrm{~N}$ relative to ${ }^{18} \mathrm{O}$ by a factor between 0.8 and 2.0 gives evidence for denitrification (Aravena and Robertson., 2010; Fukada et al., 2003; Xue et al., 2009). The enrichment factors $(\varepsilon)$ of denitrification can be calculated via the relation between the isotopic values and the logarithm of residual $\mathrm{NO}_{3}{ }^{-}$and are expected to fall into the range from $-40 \%$ to $-5 \%$ or for $\varepsilon^{15} \mathrm{~N}$ and from $-18 \%$ o to $-8 \%$ or $\varepsilon^{18} \mathrm{O}$ (Hubner, 1986; Bottcher et al., 1990; Smith et al., 1991; Mengis et al., 1999; Fukada et al., 2003; Sebilo et al., 2003; Knöller et al., 2011).

\section{Statistical analysis}

In this study, the principle coordinate analysis (PCoA) has been applied to evaluate the data sets of physicochemical properties of the six rivers and the corresponding estuaries and shallow groundwater samples. 


\section{Results and discussion}

\section{Physicochemical properties of the rivers and the corresponding estuaries}

The physicochemical properties and isotopic values of the water samples were shown in Table 2. The mean $\mathrm{pH}$ of the rivers and their corresponding estuaries changed from 7.4 to 8.4 , and the mean DO concentrations ranged from 4.1 to $11.2 \mathrm{mg} \mathrm{L}^{-1}$. The mean salinity of the middle rivers (2.5-3.2) except the HHup (0.7) was higher than the northern (0.5-0.7) and southern rivers (1.9-2.5). The municipality had been suffering multiple seawater intrusion and regression, which results in the salinization of the rivers and soil (Wang, 2004).

Table 2. Physicochemical properties and isotopic composition of $\mathrm{NO}_{3}{ }^{-}$for the rivers and the corresponding estuaries

\begin{tabular}{|c|c|c|c|c|c|c|c|c|c|}
\hline \multirow{2}{*}{ Location } & \multirow{2}{*}{ pH } & \multirow{2}{*}{ DO } & \multirow{2}{*}{ Salinity } & $\mathrm{Cl}^{-}$ & $\mathrm{NO}_{3}^{-}$ & $\mathbf{N H}_{4}^{+}$ & $\mathrm{NO}_{2}^{-}$ & $\delta^{15} \mathrm{~N}-\mathrm{NO}_{3}^{-}$ & $\delta^{18} \mathrm{O}-\mathrm{NO}_{3}^{-}$ \\
\hline & & & & \multicolumn{4}{|c|}{$\mathrm{mg} \mathrm{L}^{-1}$} & \multicolumn{2}{|c|}{$\%$} \\
\hline \multirow{6}{*}{$\begin{array}{c}\text { CB } \\
\text { River }\end{array}$} & 7.9 & 8.9 & 0.5 & 117.0 & 7.4 & 6.0 & 1.8 & 13.7 & 4.0 \\
\hline & 8.6 & 10.5 & 0.5 & 138.5 & 8.3 & 3.0 & 0.5 & 14.0 & 4.8 \\
\hline & 8.5 & 9.1 & 0.5 & 161.4 & 9.8 & 6.8 & 0.6 & 13.9 & 3.9 \\
\hline & 8.5 & 9.9 & 0.5 & 180.6 & 10.6 & 2.6 & 0.5 & 12.2 & 4.3 \\
\hline & 8.6 & 10.4 & 0.6 & 184.0 & 10.6 & 6.6 & 0.4 & 13.7 & 4.8 \\
\hline & 8.2 & 10.0 & 0.6 & 195.0 & 9.4 & 3.8 & 0.3 & 14.1 & 5.6 \\
\hline Mean $\pm \mathrm{SD}$ & $8.4 \pm 0.3$ & $9.8 \pm 0.7$ & $0.5 \pm 0.1$ & $162.8 \pm 30.0$ & $9.4 \pm 1.3$ & $4.8 \pm 1.9$ & $0.7 \pm 0.6$ & $13.6 \pm 0.7$ & $4.6 \pm 0.6$ \\
\hline \multirow{8}{*}{$\begin{array}{c}\text { JY } \\
\text { River }\end{array}$} & 8.1 & 7.2 & 0.6 & 171.4 & 2.5 & 1.3 & 0.3 & 6.5 & 0.9 \\
\hline & 8.2 & 8.7 & 0.7 & 194.9 & 2.6 & 1.2 & 0.3 & 6.3 & 2.0 \\
\hline & 8.2 & 7.5 & 0.7 & 206.4 & 2.7 & 1.0 & 0.2 & 6.4 & 1.4 \\
\hline & 8.4 & 9.3 & 0.7 & 215.6 & 2.9 & 0.9 & 0.2 & 5.8 & 0.8 \\
\hline & 8.4 & 9.3 & 0.8 & 233.7 & 4.7 & 0.2 & 0.3 & 5.3 & 1.3 \\
\hline & 8.4 & 9.7 & 0.8 & 251.1 & 4.8 & 0.5 & 0.2 & 5.3 & 1.1 \\
\hline & 8.5 & 9.9 & 0.8 & 254.3 & 5.2 & 0.2 & 0.1 & 4.4 & 2.8 \\
\hline & 8.5 & 9.9 & 0.8 & 254.5 & 5.1 & 0.6 & 0.1 & 4.4 & 5.3 \\
\hline Mean \pm SD & $8.3 \pm 0.2$ & $8.9 \pm 1.1$ & $0.7 \pm 0.1$ & $222.7 \pm 30.8$ & $3.8 \pm 1.2$ & $0.7 \pm 0.4$ & $0.2 \pm 0.1$ & $5.6 \pm 0.8$ & $2.0 \pm 1.5$ \\
\hline \multirow{7}{*}{$\begin{array}{c}\text { CJ } \\
\text { Estuary }\end{array}$} & 8.2 & 10.6 & 2.0 & 7028.2 & 9.5 & 5.9 & 0.2 & 13.6 & 5.9 \\
\hline & 8.2 & 11.4 & 2.5 & 4973.9 & 7.4 & 5.5 & 0.2 & 15.0 & 6.1 \\
\hline & 8.3 & 11.5 & 2.7 & 1201.1 & 6.8 & 5.1 & 0.4 & 14.7 & 6.4 \\
\hline & 8.3 & 11.1 & 4.2 & 1216.8 & 8.1 & 5.2 & 0.3 & 13.6 & 6.4 \\
\hline & 8.3 & 11.4 & 9.0 & 509.6 & 2.3 & 3.3 & 0.4 & 11.9 & 6.2 \\
\hline & 8.3 & 11.3 & 13.7 & 2172.8 & 1.5 & 2.2 & 0.3 & 9.3 & 6.7 \\
\hline & 8.2 & 11.2 & 20.0 & 9831.6 & 0.4 & 0.8 & 0.2 & 7.1 & 6.9 \\
\hline Mean \pm SD & $8.3 \pm 0.1$ & $11.2 \pm 0.3$ & $7.7 \pm 6.9$ & $3847.7 \pm 3537.1$ & $5.1 \pm 3.6$ & $4.0 \pm 1.9$ & $0.3 \pm 0.1$ & $12.2 \pm 3.0$ & $6.4 \pm 0.3$ \\
\hline \multirow{4}{*}{$\begin{array}{l}\text { HHup } \\
\text { River }\end{array}$} & 7.5 & 2.7 & 0.7 & 207.2 & 13.6 & 4.0 & 0.8 & -0.2 & -0.5 \\
\hline & 7.7 & 4.0 & 0.7 & 184.6 & 9.0 & 6.0 & 0.8 & 0.5 & 0.2 \\
\hline & 7.7 & 4.8 & 0.7 & 219.1 & 8.3 & 5.6 & 0.9 & 0.6 & 0.2 \\
\hline & 7.9 & 5.0 & 0.8 & 275.8 & 6.5 & 5.9 & 1.0 & 1.1 & 0.5 \\
\hline Mean \pm SD & $7.7 \pm 0.2$ & $4.1 \pm 1.0$ & $0.7 \pm 0.1$ & $221.7 \pm 38.8$ & $9.4 \pm 3.0$ & $5.4 \pm 0.9$ & $0.9 \pm 0.1$ & $0.5 \pm 0.5$ & $0.1 \pm 0.4$ \\
\hline \multirow{6}{*}{$\begin{array}{l}\text { HHdw } \\
\text { River }\end{array}$} & 8.1 & 8.2 & 1.0 & 408.2 & 5.9 & 2.8 & 1.0 & 4.5 & 0.6 \\
\hline & 8.4 & 10.4 & 2.3 & 1441.5 & 5.6 & 2.2 & 0.3 & 4.6 & 1.1 \\
\hline & 8.5 & 10.5 & 2.4 & 1696.6 & 5.8 & 2.3 & 0.5 & 4.3 & 1.3 \\
\hline & 8.3 & 10.4 & 3.7 & 1983.0 & 5.5 & 2.3 & 0.4 & 3.9 & 1.2 \\
\hline & 8.3 & 9.9 & 4.6 & 2673.9 & 3.9 & 2.8 & 0.7 & 8.4 & 1.5 \\
\hline & 8.2 & 9.4 & 4.9 & 3486.6 & 4.3 & 2.7 & 0.7 & 7.4 & 1.4 \\
\hline Mean $\pm \mathrm{SD}$ & $8.3 \pm 0.1$ & $9.8 \pm 0.9$ & $3.2 \pm 1.5$ & $1948.3 \pm 1057.0$ & $5.2 \pm 0.8$ & $2.5 \pm 0.3$ & $0.6 \pm 0.3$ & $5.5 \pm 1.9$ & $1.2 \pm 0.3$ \\
\hline
\end{tabular}




\begin{tabular}{|c|c|c|c|c|c|c|c|c|c|}
\hline \multirow{4}{*}{ HH Estuary } & 8.1 & 10.7 & 18.6 & 10225.6 & 1.6 & 1.6 & 0.3 & 8.0 & 5.4 \\
\hline & 8.1 & 10.7 & 20.6 & 10519.7 & 1.1 & 1.4 & 0.3 & 7.9 & 5.6 \\
\hline & 8.2 & 10.7 & 21.3 & 12202.2 & 0.9 & 1.4 & 0.3 & 8.1 & 5.7 \\
\hline & 8.2 & 10.7 & 24.1 & 13270.0 & 0.4 & 1.2 & 0.3 & 8.3 & 5.8 \\
\hline Mean \pm SD & $8.2 \pm 0.1$ & $10.7 \pm 0.0$ & $21.2 \pm 2.3$ & $11554.4 \pm 1437.5$ & $1.0 \pm 0.5$ & $1.4 \pm 0.2$ & $0.3 \pm 0.0$ & $8.1 \pm 0.2$ & $5.6 \pm 0.2$ \\
\hline \multirow{5}{*}{ DG River } & 8.1 & 9.1 & 1.8 & 707.9 & 6.0 & 2.5 & 0.7 & 7.2 & 3.0 \\
\hline & 7.0 & 5.7 & 1.7 & 699.8 & 5.3 & 14.5 & 0.4 & 8.4 & 2.9 \\
\hline & 7.2 & 3.8 & 2.3 & 1050.9 & 0.2 & 16.7 & 0.0 & 11.6 & 5.1 \\
\hline & 7.1 & 5.5 & 3.0 & 1397.3 & 3.9 & 14.2 & 0.6 & 7.7 & 0.5 \\
\hline & 7.8 & 8.7 & 3.6 & 1804.1 & 6.9 & 10.6 & 0.5 & 6.2 & 1.5 \\
\hline Mean \pm SD & $7.4 \pm 0.5$ & $6.6 \pm 2.3$ & $2.5 \pm 0.8$ & $1132.0 \pm 473.1$ & $4.4 \pm 2.6$ & $11.7 \pm 5.6$ & $0.4 \pm 0.3$ & $8.2 \pm 2.0$ & $2.6 \pm 1.7$ \\
\hline \multirow{6}{*}{ DL River } & 8.2 & 10.8 & 1.8 & 723.7 & 9.6 & 2.7 & 0.4 & 4.0 & 2.5 \\
\hline & 7.7 & 7.7 & 1.8 & 731.3 & 12.5 & 10.4 & 0.9 & 6.8 & 3.6 \\
\hline & 7.7 & 8.3 & 2.0 & 791.4 & 11.2 & 9.0 & 1.0 & 6.5 & 7.2 \\
\hline & 8.3 & 10.9 & 2.5 & 1043.5 & 12.5 & 1.2 & 0.3 & 4.3 & 2.5 \\
\hline & 8.2 & 11.3 & 2.4 & 1105.3 & 11.1 & 0.1 & 0.1 & 4.2 & 3.0 \\
\hline & 8.2 & 11.1 & 2.9 & 1410.1 & 11.2 & 2.0 & 0.0 & 6.4 & 7.7 \\
\hline Mean \pm SD & $8.1 \pm 0.3$ & $10.0 \pm 1.6$ & $2.2 \pm 0.4$ & $967.6 \pm 270.9$ & $11.4 \pm 1.1$ & $4.2 \pm 4.3$ & $0.5 \pm 0.4$ & $5.4 \pm 1.3$ & $4.4 \pm 2.4$ \\
\hline \multirow{5}{*}{ ZY River } & 7.3 & 9.1 & 1.8 & 736.7 & 5.5 & 34.3 & 2.2 & 8.2 & 7.7 \\
\hline & 7.5 & 10.1 & 1.8 & 697.9 & 5.4 & 51.9 & 2.1 & 7.9 & 8.2 \\
\hline & 7.3 & 9.1 & 1.7 & 701.4 & 4.9 & 52.4 & 1.9 & 8.7 & 9.2 \\
\hline & 7.4 & 9.4 & 1.9 & 839.8 & 4.4 & 55.7 & 2.0 & 8.9 & 8.9 \\
\hline & 7.4 & 9.3 & 2.1 & 929.3 & 2.4 & 61.2 & 1.8 & 14.1 & 13.4 \\
\hline Mean \pm SD & $7.4 \pm 0.1$ & $9.4 \pm 0.4$ & $1.9 \pm 0.2$ & $781.0 \pm 100.8$ & $4.5 \pm 1.3$ & $51.1 \pm 10.1$ & $2.0 \pm 0.2$ & $9.6 \pm 2.6$ & $9.5 \pm 2.3$ \\
\hline
\end{tabular}

The mean $\mathrm{Cl}^{-}$concentrations were relatively high, varying from 162.8 to $1948.3 \mathrm{mg} \mathrm{L}^{-1}$ for the rivers and from 3847.7 to $11554.4 \mathrm{mg} \mathrm{L}^{-1}$ for the estuaries. Both the salinization and anthropogenic activities, such as sewage and livestock effluent can cause relatively high $\mathrm{Cl}^{-}$concentrations in the rivers (Yao et al., 2007). The relatively higher mean $\mathrm{NO}_{3}^{-}$concentrations appeared in the rivers of DL $\left(11.4 \mathrm{mg} \mathrm{L}^{-1}\right), \mathrm{CB}$ (9.4 $\left.\mathrm{mg} \mathrm{L}^{-1}\right)$ and the HHup $\left(9.4 \mathrm{mg} \mathrm{L}^{-1}\right)$; the relatively lower mean $\mathrm{NO}_{3}{ }^{-}$concentrations appeared in the rivers of $\mathrm{JY}\left(3.8 \mathrm{mg} \mathrm{L}^{-1}\right)$. The mean $\mathrm{NO}_{3}{ }^{-}$concentrations of the estuaries were $5.1 \mathrm{mg} \mathrm{L}^{-1}$ for the CJ Estuary and $1.0 \mathrm{mg} \mathrm{L}^{-1}$ for the $\mathrm{HH}$ Estuary. The mean $\mathrm{NH}_{4}{ }^{+}$ concentrations varied largely from 0.7 to $51.1 \mathrm{mg} \mathrm{L}^{-1}$. The highest mean $\mathrm{NH}_{4}^{+}$ concentration appeared in the ZY River because of intensive industry along the upstream of the river and large volume discharge of low treatment rate of sewage (He and Huang, 2013).

The mean $\mathrm{NO}_{2}^{-}$concentrations of the rivers and their corresponding estuaries changed from 0.2 to $2.0 \mathrm{mg} \mathrm{L} \mathrm{L}^{-1}$. The isotopic composition of $\mathrm{NO}_{3}^{-}$varied spatially

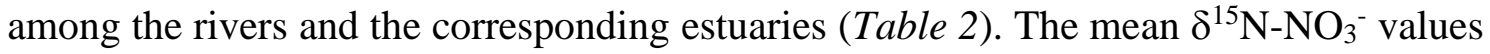
varied from 0.5 to $13.6 \%$ and the mean $\delta^{18} \mathrm{O}-\mathrm{NO}_{3}{ }^{-}$values varied from 0.1 to $9.5 \%$. The relatively large isotopic range potentially indicates that the rivers and estuaries were influenced by complex $\mathrm{NO}_{3}{ }^{-}$sources.

The PCoA results revealed that the rivers and the corresponding estuaries were divided into three parts (Fig. 2). The rivers of CB, JY and HHup with low salinity located in the north of Tianjin were grouped together, while the rivers of HHdw, DG, DL and ZY with high salinity were grouped together. The residual two estuaries (CJ and $\mathrm{HH})$ were grouped together with highest salinity. 


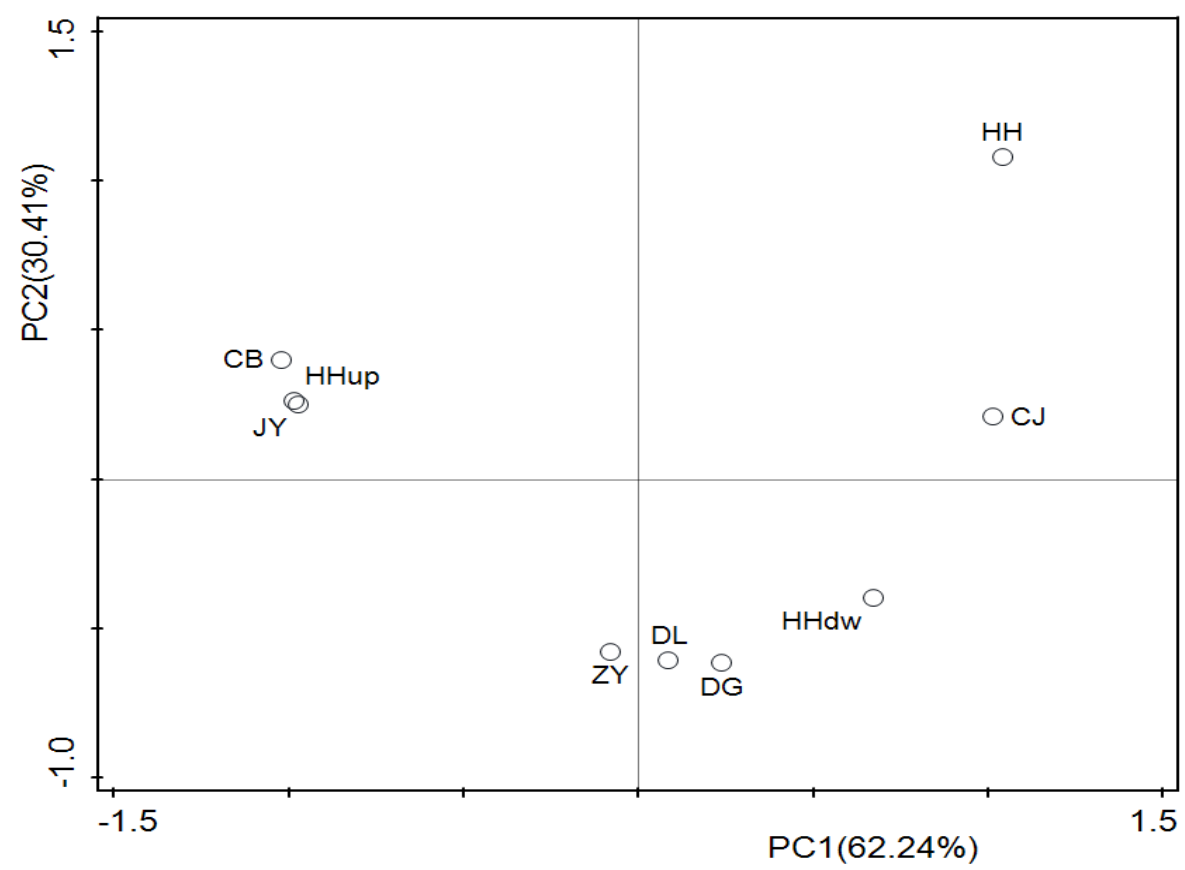

Figure 2. Principle coordinate analysis for physicochemical properties of the six Rivers and the corresponding Estuaries. CB, JY, HHup, HHdw, DL, ZY and DG River are the abbreviations of the Chaobaixin River, the Jiyun River, the upstream of the Haihe River, the downstream of the Haihe River, the Duliujian River, the Ziyaxin River and the Dagu sewage River, respectively. CJ, HH are the abbreviations of the CJ Estuary (co-estuary of the JY and the CB River) and Haihe Estuary, respectively

\section{Physicochemical properties of the SG}

The physicochemical properties and isotopic values of the SG were shown in Table 3. The average $\mathrm{pH}$ of SG in May and November was 7.1 and 7.4, with a range between 6.6 to 7.8 and 6.9 to 8.2 , respectively. The mean DO was $4.6 \mathrm{mg} \mathrm{L}^{-1}$ and $5.9 \mathrm{mg} \mathrm{L}^{-1}$, and varied from 1.9 to $7.9 \mathrm{mg} \mathrm{L}^{-1}$ and 1.7 to $8.4 \mathrm{mg} \mathrm{L}^{-1}$, respectively. The average salinity and its variations ranged between 0.4 to 3.2 with a mean value of 1.1 in May and between 0.4 to 3.3 with a mean value of 1.2 in November, respectively.

The mean $\mathrm{Cl}^{-}$concentrations in SG were higher in May $\left(1085.2 \mathrm{mg} \mathrm{L}^{-1}\right)$ than that in November (420.1 mg L$~^{-1}$ ), with a maximum $\mathrm{Cl}^{-}$concentration achieved as high as $2704.3 \mathrm{mg} \mathrm{L}^{-1}$. The average concentration of $\mathrm{NO}_{3}{ }^{-}$in May was $117.5 \mathrm{mg} \mathrm{L}^{-1}$ lower than that of $159.8 \mathrm{mg} \mathrm{L}^{-1}$ in November. The variation was in a large range, from 0.3 to $221.9 \mathrm{mg} \mathrm{L}^{-1}$ and 6.7 to $360.3 \mathrm{mg} \mathrm{L}^{-1}$ in May and November, respectively.

The average concentrations of $\mathrm{NO}_{2}^{-}$in November and May were $0.06 \mathrm{mg} \mathrm{L}^{-1}$ and $0.06 \mathrm{mg} \mathrm{L}^{-1}$, with a range from 0.01 to $0.15 \mathrm{mg} \mathrm{L}^{-1}$ and 0.01 to $0.21 \mathrm{mg} \mathrm{L}^{-1}$, respectively. The average concentration of $\mathrm{NH}_{4}{ }^{+}$was $0.3 \mathrm{mg} \mathrm{L}^{-1}$ and $0.2 \mathrm{mg} \mathrm{L}^{-1}$ in May and November, with variations ranging from 0 to $0.9 \mathrm{mg} \mathrm{L}^{-1}$ and 0 to $1.0 \mathrm{mg} \mathrm{L}^{-1}$, respectively. The $\delta^{15} \mathrm{~N}^{-N_{3}}{ }_{3}^{-}$values varied from +10.2 to $+45.9 \%$ and +2.9 to $+38.2 \%$ o in May and November, with a mean $\delta^{15}{\mathrm{~N}-\mathrm{NO}_{3}}^{-}$value of $+22.5 \%$ and $+13.5 \%$, respectively. The average value of $\delta^{18} \mathrm{O}-\mathrm{NO}_{3}{ }^{-}$was relatively close in May $(+9.9 \%)$ and November $(+10.8 \%$ ) , ranging from -7.9 to $+28.4 \%$ and +2.2 to $+22.6 \%$.

The PCoA results revealed that groundwater sampling points of Jixian, Wuqing and Dagang were grouped into three parts (Fig. 3) based on their spatial locations. 
Table 3. Physicochemical properties and isotopic composition of $\mathrm{NO}_{3}{ }^{-}$for the shallow groundwater

\begin{tabular}{|c|c|c|c|c|c|c|c|c|c|c|}
\hline \multirow{2}{*}{ Season } & \multirow{2}{*}{$\begin{array}{c}\text { Sampling } \\
\text { point }\end{array}$} & \multirow{2}{*}{$\mathbf{p H}$} & \multirow{2}{*}{$\begin{array}{c}\text { Salinity } \\
(\mathbf{p p t}) \\
\end{array}$} & DO & $\mathrm{Cl}^{-}$ & $\mathrm{NO}_{3}^{-}$ & $\mathrm{NO}_{2}^{-}$ & $\mathbf{N H}_{4}{ }^{+}$ & $\delta^{15} \mathbf{N}-\mathrm{NO}_{3}^{-}$ & $\delta^{18} \mathrm{O}-\mathrm{NO}_{3}^{-}$ \\
\hline & & & & \multicolumn{5}{|c|}{$\mathrm{mg} / \mathrm{L}$} & \multicolumn{2}{|c|}{ \%o } \\
\hline \multirow{7}{*}{ May } & JX1 & 6.6 & 0.5 & 7.9 & 640.6 & 238.0 & 0.04 & 0.0 & 19.6 & 7.5 \\
\hline & JX2 & 6.9 & 0.5 & 7.3 & 40.0 & 221.9 & 0.03 & 0.0 & 10.4 & 0.9 \\
\hline & $\mathrm{JX} 3$ & 6.6 & 0.4 & 4.4 & 551.0 & 128.1 & 0.02 & 0.0 & 10.2 & -7.9 \\
\hline & WQ1 & 7.5 & 1.2 & 2.6 & 1291.6 & 0.3 & 0.01 & 0.9 & 31.0 & 28.4 \\
\hline & WQ2 & 7.2 & 0.9 & 1.9 & 1283.5 & 59.8 & 0.04 & 0.8 & 17.6 & 8.7 \\
\hline & DG & 7.8 & 3.2 & 3.5 & 2704.3 & 56.9 & 0.21 & 0.0 & 45.9 & 21.9 \\
\hline & $\begin{array}{c}\text { Mean } \pm S \\
D\end{array}$ & $\begin{array}{c}7.1 \pm 0 . \\
4\end{array}$ & $1.1 \pm 0.9$ & $\begin{array}{c}4.6 \pm 2 . \\
3\end{array}$ & $\begin{array}{c}1085.2 \pm 844 \\
5\end{array}$ & $117.5 \pm 87.8$ & $0.06 \pm 0.07$ & $0.3 \pm 0.4$ & $22.5 \pm 12.6$ & $9.9 \pm 12.2$ \\
\hline \multirow{7}{*}{ November } & $\mathrm{JX} 1$ & 7.1 & 0.6 & 8.4 & 64.4 & 276.1 & 0.02 & 0.0 & 10.7 & 5.4 \\
\hline & $\mathrm{JX} 2$ & 7.2 & 0.6 & 7.7 & 62.0 & 360.3 & 0.03 & 0.0 & 3.2 & 7.1 \\
\hline & JX3 & 6.9 & 0.4 & 3.4 & 44.3 & 186.9 & 0.01 & 0.0 & 2.9 & 2.2 \\
\hline & WQ1 & 7.5 & 1.1 & 7.3 & 424.8 & 6.7 & 0.14 & 1.0 & 15.5 & 17.0 \\
\hline & WQ2 & 7.3 & 1.1 & 1.7 & 272.2 & 74.1 & 0.15 & 0.2 & 10.5 & 10.6 \\
\hline & DG & 8.2 & 3.3 & 6.8 & 1652.7 & 54.7 & 0.03 & 0.1 & 38.2 & 22.6 \\
\hline & $\begin{array}{c}\text { Mean } \pm S \\
D\end{array}$ & $\begin{array}{c}7.4 \pm 0 \\
4\end{array}$ & $1.2 \pm 0.9$ & $\begin{array}{c}5.9 \pm 2 . \\
5\end{array}$ & $420.1 \pm 568.2$ & $\begin{array}{c}159.8 \pm 126 \\
7\end{array}$ & $0.06 \pm 0.06$ & $0.2 \pm 0.3$ & $13.5 \pm 11.9$ & $10.8 \pm 7.0$ \\
\hline
\end{tabular}

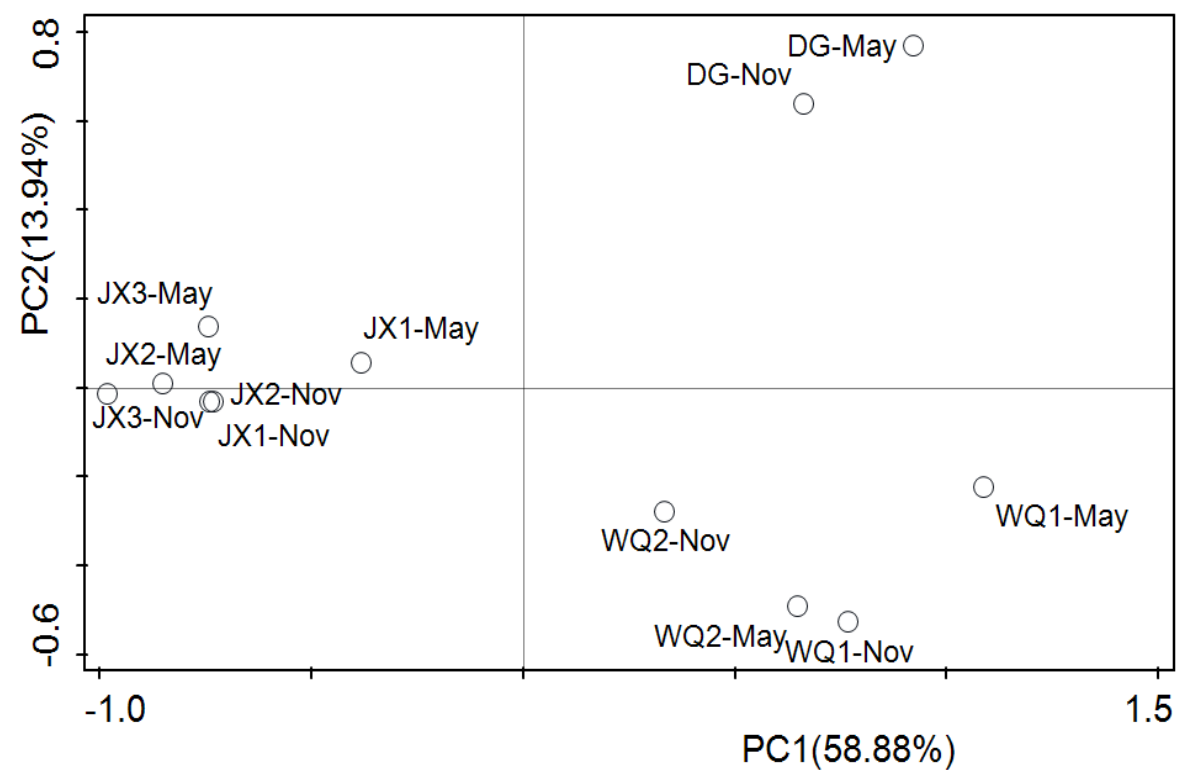

Figure 3. Principle coordination analysis for physicochemical properties of the shallow groundwater. DG, JX and $W Q$ are the abbreviations of Dagang, Jixian and Wuqing, which are all located in the outskirts of Tianjin. Number represent different sampling locations and-May and-Nov represent samples were sampled in mid-May and mid-November, during dry and wet periods, respectively

\section{Potential $\mathrm{NO}_{3}{ }^{-}$source identification for the rivers and the corresponding estuaries}

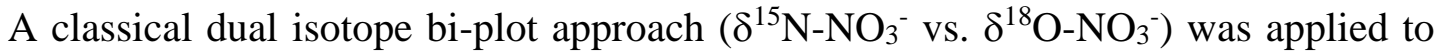
identify the potential dominant $\mathrm{NO}_{3}{ }^{-}$sources in different rivers and the corresponding estuaries (Fig. 4). It is clear that the predominant $\mathrm{NO}_{3}$ " sources are "Soil" and/or "M\&S" for the HH River, the CB River, the JY River, the CJ and the HH Estuary. The isotopic 
signatures of the DL River were mainly concentrated in the "Soil" source box, indicating $\mathrm{NO}_{3}{ }^{-}$derived from soil organic, $\mathrm{N}$. The $\delta^{15} \mathrm{~N}$ - and $\delta^{18} \mathrm{O}-\mathrm{NO}_{3}{ }^{-}$values of the DG River and the ZY River were distributed in the source box of "M\&S". In general, more than half of the sampling locations were mainly influenced by "manure" and/or sewage, but it is difficult to specify whether the predominant $\mathrm{NO}_{3}{ }^{-}$source is from only one or both two sources based on the bi-plot.

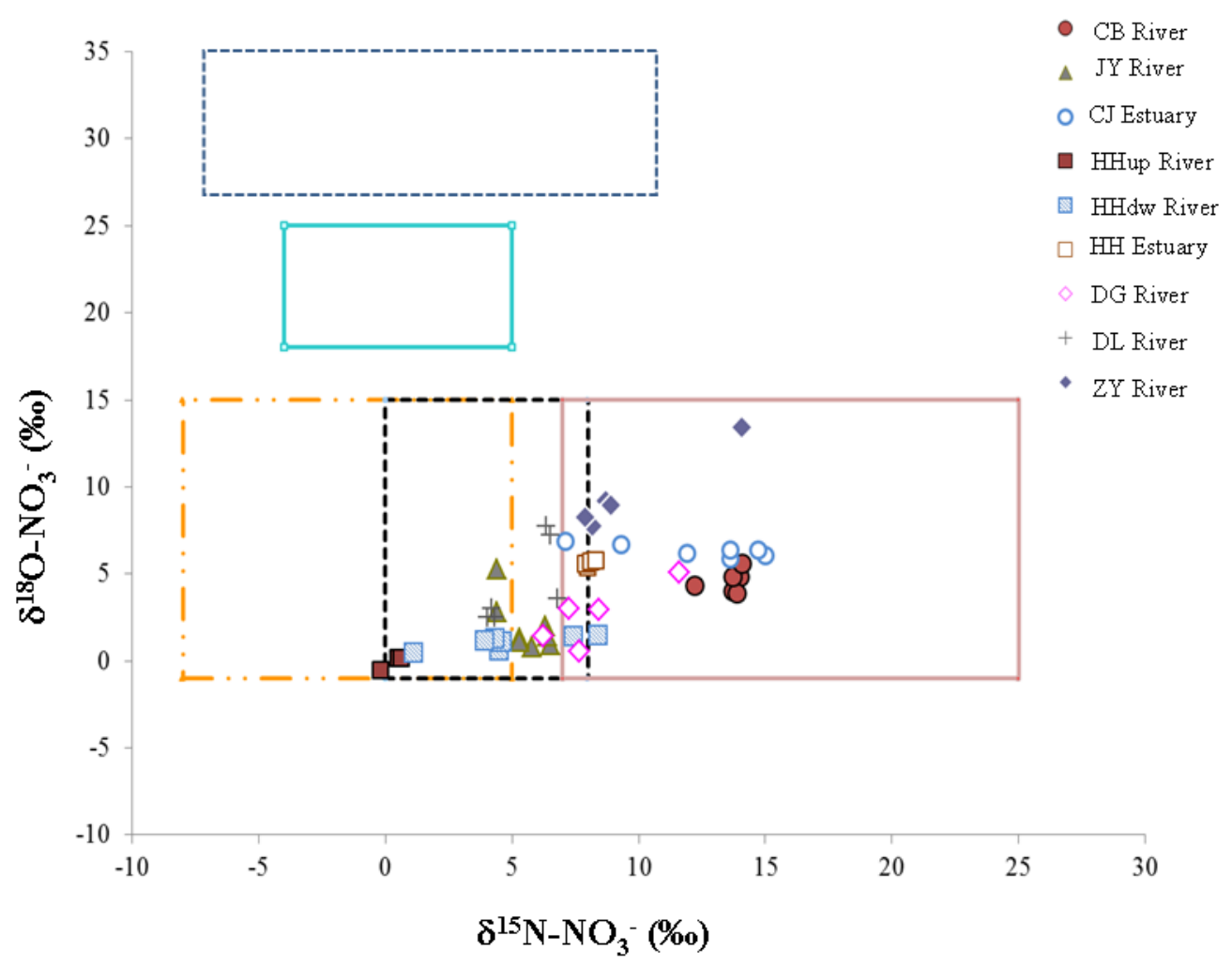

Figure 4. The $\delta^{15} \mathrm{~N}$ - and $\delta^{18} \mathrm{O}-\mathrm{NO}_{3}{ }^{-}$of the rivers and the corresponding estuaries. $\mathrm{CB}, \mathrm{JY}$, HHup, HHdw, DL, ZY and DG River are the abbreviations of the Chaobaixin River, the Jiyun River, the upstream of the Haihe River, the downstream of the Haihe River, the Duliujian River, the Ziyaxin River and the Dagu sewage River, respectively. CJ, HH are the abbreviations of the $C J$ Estuary (co-estuary of the JY and the CB River) and Haihe Estuary, respectively. Ranges of the isotopic composition for five potential $\mathrm{NO}_{3}{ }_{3}^{-}$sources are adapted from Kendall et al. (2007) and Xue et al. (2009) and indicated by boxes: $\mathrm{NO}_{3}{ }^{-}$in precipitation $(\mathrm{NP}), \mathrm{NO}_{3}{ }^{-}$fertilizer $(\mathrm{NF})$, $\mathrm{NH}_{4}{ }^{+}$in fertilizer and rain (NF\&R), soil $N$ (Soil) and manure and sewage (M\&S). To provide a wider and clear range of $\delta^{18} \mathrm{O}-\mathrm{NO}_{3}^{-}$values, the upper limit of $\mathrm{NP}$ reaches $35 \%$

$\mathrm{Cl}^{-}$is a useful indicator for contamination source tracking. High levels of $\mathrm{Cl}^{-}$have been detected in sewage and livestock effluent (Yao et al., 2007). Thus, a plot of $\delta^{15} \mathrm{~N}$ $\mathrm{NO}_{3}{ }^{-}$vs. $\mathrm{NO}_{3}{ }^{-} / \mathrm{Cl}^{-}$molar ratio might reveal further detailed information for source identification (Fig. 5). As shown in Figure 5, in the "M\&S" source box, the majority of the rivers and estuaries were potentially influenced by four sources: (a) extremely low $\mathrm{NO}_{3}{ }^{-} / \mathrm{Cl}^{-}$molar ratio and relatively low $\delta^{15} \mathrm{~N}^{-\mathrm{NO}_{3}}{ }^{-}$values (mainly appeared in the $\mathrm{HH}$ Estuary, box A in Fig. 5); (b) relatively low $\mathrm{NO}_{3}{ }^{-} / \mathrm{Cl}^{-}$molar ratio and high $\delta^{15} \mathrm{~N}^{-\mathrm{NO}_{3}}{ }^{-}$ values (mainly appeared in the CJ Estuary, box B in Fig. 5); (c) high $\mathrm{NO}_{3}{ }^{-} / \mathrm{Cl}^{-}$molar ratio and high $\delta^{15} \mathrm{~N}^{-N_{3}}{ }^{-}$values (mainly appeared in the CB River, box C in Fig. 5); 
and (d) relatively low $\mathrm{NO}_{3}{ }^{-} / \mathrm{Cl}^{-}$molar ratio and relatively low $\delta^{15} \mathrm{~N}^{-\mathrm{NO}_{3}}{ }^{-}$values (mainly appeared in the ZY River, box D in Fig. 5). Since the HH River discharge was limited due to the floodgate at the end, the HH Estuary (box A) and the highest salinity sampling location of the CJ Estuary might be regarded as the coast end-member. The last two sampling locations of the HH River were obvious to be influenced by seawater from the HH Estuary not sewage. There are mooring ships in the vicinity of the CJ Estuary all year around, domestic sewage is the main $\mathrm{NO}_{3}{ }^{-}$source in this estuary. Thus, the CJ Estuary (box B) can be considered as domestic sewage end-member. Along with point-source contamination was diluted by estuarine water, the residual sampling locations of the CJ Estuary were close to the HH Estuary end-member (box A). The CB River (box $\mathrm{C}$ ) was considered as the manure end-member, as this watershed plays the role of important livestock breeding base for the municipality (Shao et al., 2010). Furthermore, the $\delta^{15} \mathrm{~N}_{-} \mathrm{NO}_{3}{ }^{-}$values were enriched and varied around $14 \%$, indicating anthropogenic $\mathrm{NO}_{3}{ }^{-}$derived from manure (Kendall et al., 2007; Xue et al., 2009). The ZY River (box D) was considered as the industrial sewage end-member, as industry was intensively distributed along the upstream of the river and low treatment rate of sewage was largely discharged into the river. The data distribution of the DG River is quite scattered, possibly resulting from multiple $\mathrm{NO}_{3}{ }^{-}$source inputs.

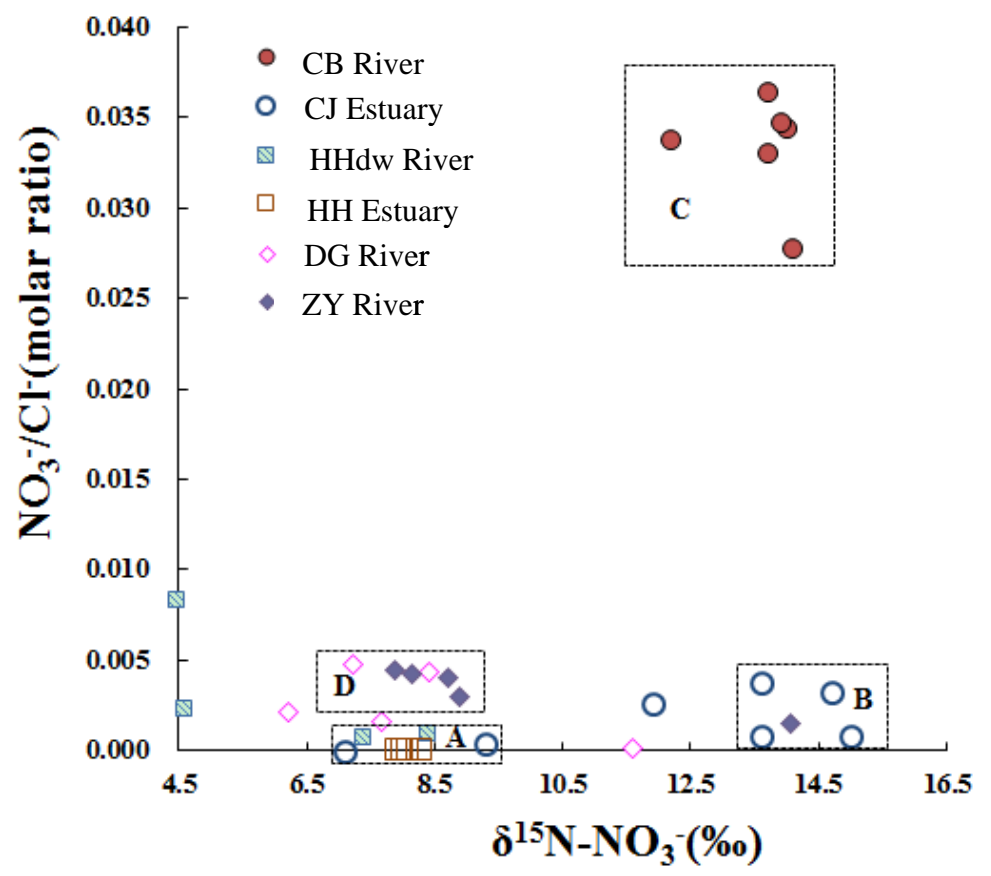

Figure 5. The $\mathrm{NO}_{3}{ }^{-} / \mathrm{Cl}^{-}$molar ratio versus the nitrogen isotope of $\mathrm{NO}_{3}{ }^{-}$in the rivers and the corresponding estuaries. Boxes $A, B, C$, and D represent different end-members. $C B, H H d w, Z Y$ and $D G$ River are the abbreviations of the Chaobaixin River, the downstream of the Haihe River, the Ziyaxin River and the Dagu sewage River, respectively. CJ, HH are the abbreviations of the CJ Estuary (co-estuary of the JY and the CB River) and Haihe Estuary, respectively

Wide ranges of the $\delta^{15} \mathrm{~N}$ - and $\delta^{18} \mathrm{O}-\mathrm{NO}_{3}{ }^{-}$values of the rivers and corresponding estuaries showed that surface waters in Tianjin are mainly influenced by multiple $\mathrm{NO}_{3}{ }^{-}$ sources, but dominated by one or two. To get more specific information, a more quantitative technique based on isotopic mixing model has been applied. 


\section{Potential $\mathrm{NO}_{3}^{-}$source identification for the $\mathrm{SG}$}

As shown in Figure 6, the values of $\delta^{15} \mathrm{~N}$ - and $\delta^{18} \mathrm{O}-\mathrm{NO}_{3}{ }^{-}$seasonally varied in a wide range and increased from north to south (along the direction of groundwater flow), resulting in a linear positive correlation of 0.82 and 0.53 , which indicated that significant denitrification occurred in SG (Xue et al., 2009; Aravena and Robertson, 2010; Fukada et al., 2003; Mengis et al., 2005). In the northern part of SG, the lower $\delta^{15} \mathrm{~N}$ - and $\delta^{18} \mathrm{O}-\mathrm{NO}_{3}{ }^{-}$values were mainly located in the "M\&S" source box in May and in the "NF\&R" and "Soil" in November.

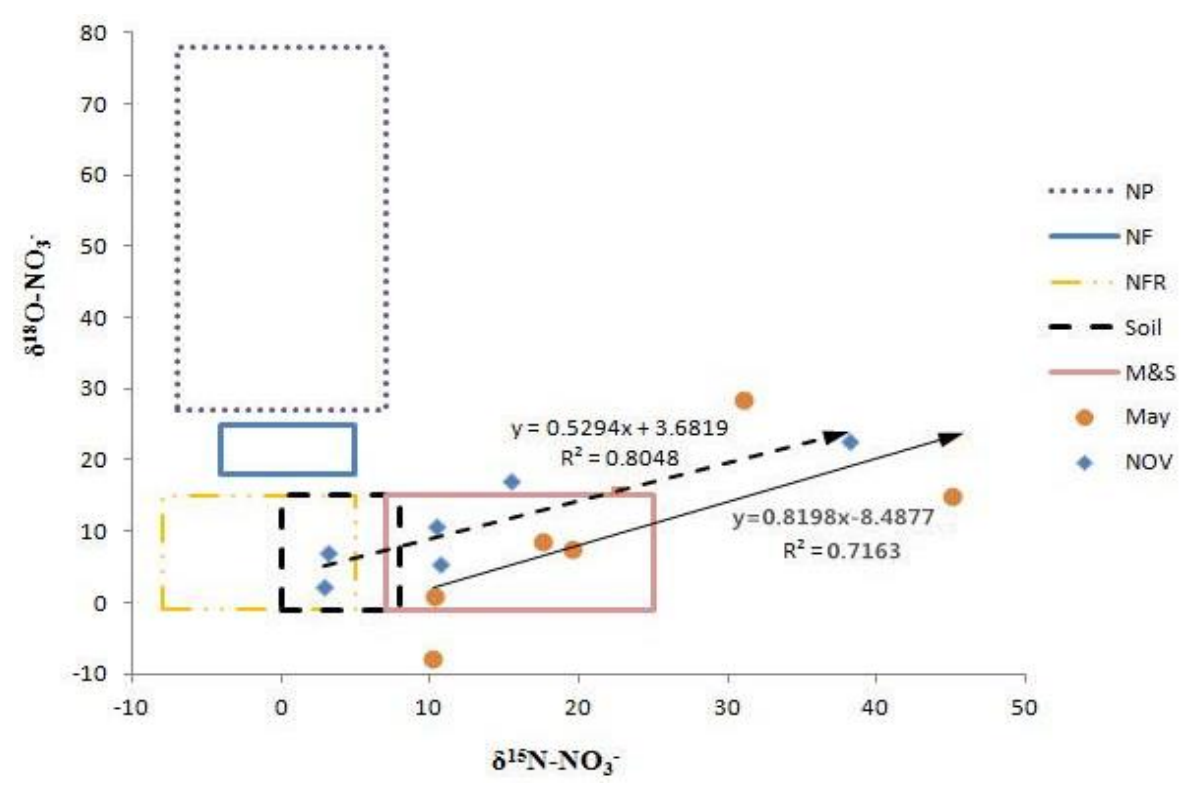

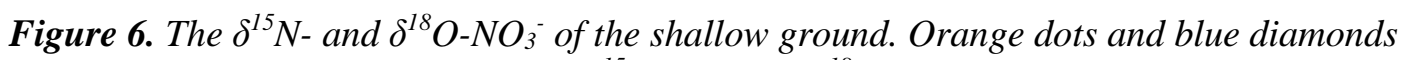
represent the distribution area of the $\delta^{15} \mathrm{~N}_{-} \mathrm{NO}_{3}^{-}$and $\delta^{18} \mathrm{O}_{-} \mathrm{NO}_{3}^{-}$during May and November, respectively. $\mathrm{NP}, \mathrm{NF}, \mathrm{NF} \& \mathrm{R}, \mathrm{Soil}, \mathrm{M} \& \mathrm{~S}$ are the abbreviations of $\mathrm{NO}_{3}^{-}$in precipitation, $\mathrm{NO}_{3}$

fertilizer, $\mathrm{NH}_{4}{ }^{+}$in fertilizer and rain, soil $\mathrm{N}$ and manure and sewage, respectively

\section{Potential $\mathrm{NO}_{3}^{-}$source contributions estimated from the rivers and the corresponding estuaries by SIAR}

The SIAR mixing model was applied to estimate proportional contributions of five potential $\mathrm{NO}_{3}{ }^{-}$sources (NP, NF, NF\&R, Soil and M\&S). The observed linear relationship between the $\delta^{15} \mathrm{~N}$ - and $\delta^{18} \mathrm{O}-\mathrm{NO}_{3}{ }^{-}$values of the rivers and the corresponding estuaries indicated that no obvious denitrification occurred. The mean oxygen concentrations of all surface waters were above $4.1 \mathrm{mg} \mathrm{L}^{-1}$, which is not ideal for denitrification (Piña-Ochoa et al., 2006). Thus, we assumed parameter $c_{j k}=0$ in Equation 2.

The SIAR mixing model outputs revealed a high variability in contributions of the five potential $\mathrm{NO}_{3}{ }^{-}$sources to the rivers and the corresponding estuaries as shown in Figure 7. The overall mean contributions of each $\mathrm{NO}_{3}{ }^{-}$source to the study area are as follows: "M\&S" contributed 35\%, "Soil" contributed 27\%, "NF\&R" contributed 20\%, "NF" contributed 12\%, and "NP" contributed 6\% (dash line in Fig. 7). The combination of "M\&S" and "Soil" contributions occupied more than $60 \%$ in total, which are considered as the dominant $\mathrm{NO}_{3}{ }^{-}$sources for the rivers and the corresponding estuaries. 

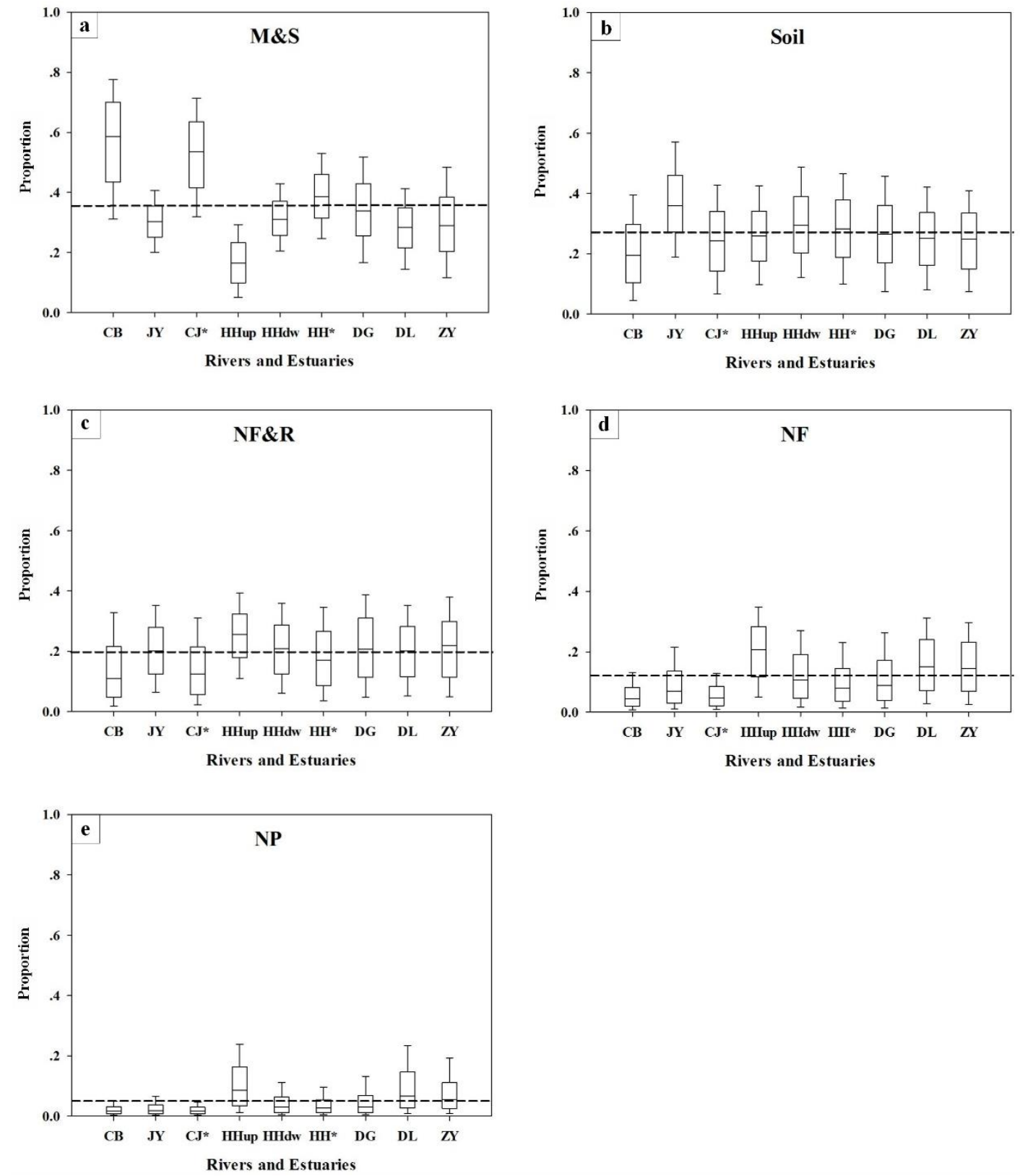

Figure 7. Contribution proportions of $\mathrm{NO}_{3}$ - sources to the rivers and the corresponding estuaries estimated by SIAR. The dash line in each graph represents the overall mean proportional contribution of the corresponding $\mathrm{NO}_{3}{ }^{-}$source. $\mathrm{CJ}^{*}$ represents the CJ Estuary, $H^{*}$ represents the $H H$ Estuary. $N P, N F, N F \& R$, Soil, $M \& S$ are the abbreviations of $\mathrm{NO}_{3}{ }^{-}$in precipitation, $\mathrm{NO}_{3}{ }^{-}$fertilizer, $\mathrm{NH}_{4}{ }^{+}$in fertilizer and rain, soil $\mathrm{N}$ and manure and sewage, respectively

The highest contribution source, the "M\&S" demonstrated a wide range of proportional contributions for most of the rivers and estuaries, with mean proportions from 17 to $56 \%$. In general, the "M\&S" contributed more for the northern rivers and estuary than the rivers and estuary in the middle and southern area. Relatively high mean proportional contributions were observed for the CB River and the CJ Estuary, up to $56 \%$ and $52 \%$, respectively. The reason could be that the watershed of the CB River 
is the base of livestock breeding for the municipality. Thus, manure showed significant effect on $\mathrm{NO}_{3}{ }^{-}$of the river. Furthermore, the CJ Estuary is not only influenced by the CB River, but also greatly influenced by sewage because of the mooring ships in the vicinity of the estuary. For the middle and southern rivers of the municipality, the mean contributions of the "M\&S" fluctuated in a narrow range between 28 and 39\%, excluding the HHup (17\%).

The source of "Soil" is another important potential source of $\mathrm{NO}_{3}$ " for the rivers and the estuaries, which contributed with the mean proportions ranging from 21 to $37 \%$. In addition, "Soil" is the highest contributing $\mathrm{NO}_{3}$ " source to the rivers of $\mathrm{JY}$ and HHup, occupying $37 \%$ and $26 \%$ contribution, respectively. This finding revealed that the dominant $\mathrm{NO}_{3}{ }^{-}$source of the two rivers mainly originated from nitration of nitrogenous organic matter mineralization.

The mean contributions of the residual three $\mathrm{NO}_{3}{ }^{-}$sources occupied about $40 \%$ in total, and the mean contribution from high to low are as follows "NF\&R" (14$25 \%)>$ "NF" (6-20\%) > "NP" (2-11\%). It has been observed that the contribution pattern of the three $\mathrm{NO}_{3}{ }^{-}$sources is quite similar for the rivers and estuaries, indicating spatial consistency of the source distribution.

Although the SIAR model overcome the questions, e.g. multiple $\mathrm{NO}_{3}{ }^{-}$sources, isotopic fractionation and spatial variability of $\delta^{15} \mathrm{~N}-$ and $\delta^{18} \mathrm{O}-\mathrm{NO}_{3}{ }^{-}$values, the limitation of the SIAR model cannot be neglected. The relatively wide ranges of $\delta^{15} \mathrm{~N}$ and $\delta^{18} \mathrm{O}-\mathrm{NO}_{3}{ }^{-}$values of the five potential $\mathrm{NO}_{3}{ }^{-}$sources resulted in the contribution ranges estimated by SIAR are wide as well. Furthermore, the isotopic composition of $\mathrm{NO}_{3}{ }^{-}$in part of the samples appeared in the overlapping area of different $\mathrm{NO}_{3}{ }^{-}$source boxes, in which even small variations in isotopic values of $\mathrm{NO}_{3}{ }^{-}$might result in large changes in source distribution. To improve the SIAR outputs, it is essential to narrow the isotopic ranges of the potential $\mathrm{NO}_{3}{ }^{-}$sources.

\section{Potential $\mathrm{NO}_{3}^{-}$source contributions estimated from the SG by SIAR}

According to the output of the SIAR mixed model, the $\mathrm{NO}_{3}{ }^{-}$contribution proportions of the potential $\mathrm{NO}_{3}$ - sources to the $\mathrm{SG}$ in Tianjin demonstrated seasonal similarity (Fig. 8): "M\&S" > "Soil" > "NF\&R" > "NF" > "NP".
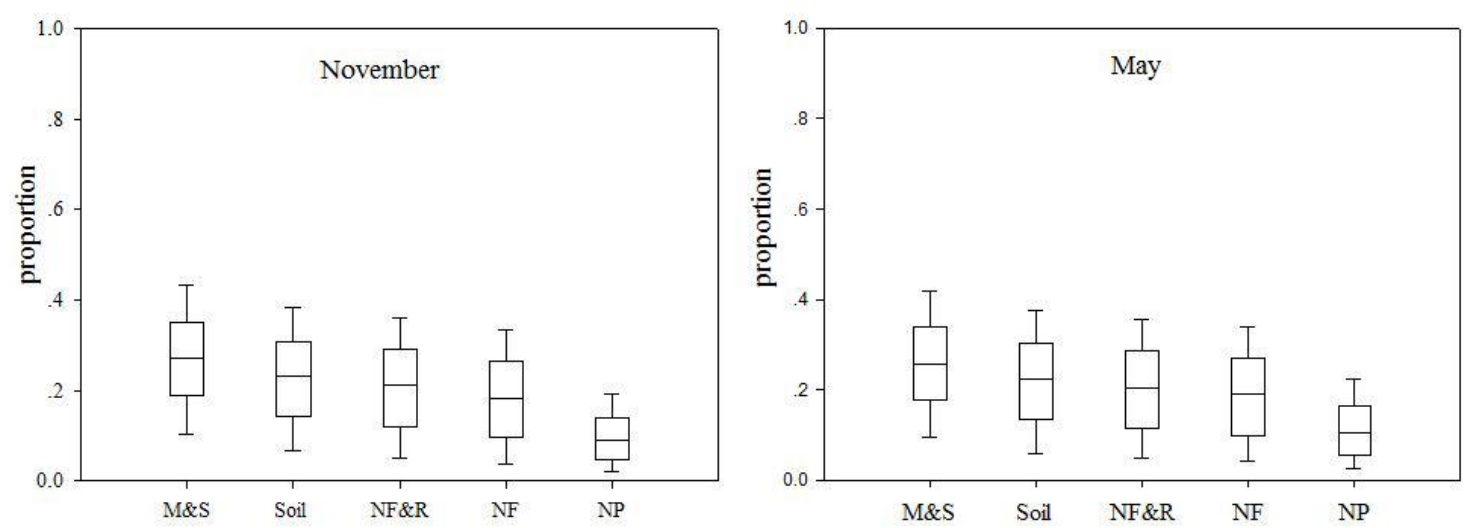

Figure 8. Contribution proportions of $\mathrm{NO}_{3}{ }^{-}$sources in May and November to the shallow groundwater estimated by SIAR. NP, NF, NF\&R, Soil, $M \& S$ are the abbreviations of $N_{3}{ }^{-}$in precipitation, $\mathrm{NO}_{3}{ }^{-}$fertilizer, $\mathrm{NH}_{4}{ }^{+}$in fertilizer and rain, soil $\mathrm{N}$ and manure and sewage, respectively 
In November and May, "M\&S" contributed an average proportion of $27.4 \%$ and $26.2 \%$, respectively; "Soil" averagely contributed about $23.0 \%$ and $21.0 \%$, respectively; "NF\&R" mean contribution was $21.0 \%$ and $20.7 \%$, respectively; "NF" mean contribution was $18.6 \%$ and $19.2 \%$, respectively, and "NP" was $10.0 \%$ and $11.6 \%$, respectively. Compared with rivers and estuaries, there was small difference in the contribution proportions among $\mathrm{NO}_{3}{ }^{-}$sources. The mean contribution proportions of "M\&S", "Soil" and "NF\&R" occupied about $70 \%$ in total. The residual $30 \%$ contribution originated from "NF" and "NP". Although atmospheric precipitation is an important water supply for $\mathrm{SG}$, it is not the main $\mathrm{NO}_{3}{ }^{-}$source in this research area.

\section{Conclusion}

Extensive agricultural activity, increasing population and rapid development of urbanization resulted in high $\mathrm{NO}_{3}{ }^{-}$levels in the rivers, the corresponding estuaries and the shallow groundwater in the coastal municipality of Tianjin in China. Identification and quantification of different $\mathrm{NO}_{3}{ }^{-}$sources are imperative to control water quality in this area. By combining dual isotope data of $\mathrm{NO}_{3}{ }^{-}\left(\delta^{15} \mathrm{~N}_{-} \mathrm{NO}_{3}{ }^{-}\right.$and $\left.\delta^{18} \mathrm{O}-\mathrm{NO}_{3}{ }^{-}\right)$with a Bayesian isotope mixing model (SIAR), we estimated the contribution of five potential $\mathrm{NO}_{3}{ }^{-}$sources for the rivers, estuaries and the SG. Despite of some uncertainties, SIAR performed reasonably well in estimating the contributions of potential $\mathrm{NO}_{3}{ }^{-}$sources. Future research required to improve the SIAR outputs by using original source material, which might provide more narrow ranges of the isotopic composition of $\mathrm{NO}_{3}{ }^{-}$sources. In addition, $\mathrm{NO}_{3}{ }^{-}$source apportionment should consider temporal variations. In general, the finding from this research may help to develop better nitrogen management practices in other environments where $\mathrm{NO}_{3}{ }^{-}$is a major $\mathrm{N}$ contributor.

Acknowledgements. We gratefully acknowledge Linzhen Guo and Mengfan Yang for soil sampling. This work was financially supported by the Ministry of Science and Technology of the People's Republic of China (2018YFD0800400), the National Natural Science Foundation of China (41973017), the Natural Science Foundation of Tianjin (19JCZDJC40700).

\section{REFERENCES}

[1] Aravena, R., Robertson, W. D. (2010): Use of multiple isotope tracers to evaluate denitrification in ground water: study of nitrite from a large-flux septic system plume. Groundwater 36(6): 975-982.

[2] Chang, C. C. Y., Kendall, C., Silva, S. R., Battaglin, W. A., Campbell, D. H. (2002): Nitrate stable isotopes: tools for determining nitrate sources among different land uses in the Mississippi River Basin. - Canadian Journal of Fisheries and Aquatic Sciences 59: 1874-1885.

[3] Chen, D. J. Z., Macquarrie, K. T. B. (2015): Correlation of $\delta^{15} \mathrm{~N}$ and $\delta^{18} \mathrm{O}$ in $\mathrm{NO}_{3}{ }^{-}$during denitrification in groundwater. - Journal of Environmental Engineering and Science 4(3): 221-226.

[4] Chen, F., Jia, G. D., Chen, J. (2009): Nitrate sources and watershed denitrification inferred from nitrate dual isotopes in the Beijiang River, south China. - Biogeochemistry 94: 163-174.

[5] Chen, L., Li, J., Guo, X., Fu, B. (2000): Temporal and spatial characteristics of surface water quality in Jiyun River. - Chinese Journal of Environmental Science 21: 61-64 (in Chinese with English abstract). 
[6] Deutsch, B., Mewes, M., Liskow, I., Voss, M. (2006): Quantification of diffuse nitrate inputs into a small river system using stable isotopes of oxygen and nitrogen in nitrate. Organic Geochemistry 37: 1333-1342.

[7] Ding, J., Li, B., Gao, R., He, L., Liu, H., Dai, X., Yu, Y. (2014): Identifying diffused nitrate sources in a stream in an agricultural field using a dual isotopic approach. Science of the Total Environment 484: 10-18.

[8] Ding, Y., Rong, N., Shan, B. (2016): Impact of extreme oxygen consumption by pollutants on macroinvertebrate assemblages in plain rivers of the Ziya River basin, North China. - Environmental Science \& Pollution Research 23(14): 14147-14156.

[9] Dong, L., Bai, H., Xu, J. (2007): Comprehensive ecological environment evaluation of estuaries in Tianjin. - Binhai New Area Plan 7: 1-3 (in Chinese with English abstract).

[10] Frey, C., Hietanen, S., Jürgens, K., Labrenz, M., Voss, M. (2014): N and O isotope fractionation in nitrate during chemolithoautotrophic denitrification by Sulfurimonas gotlandica. - Environmental Science \& Technology 48(22): 13229-37.

[11] Fukada, T., Hiscock, K. M., Dennis, P. F., Grischek, T. (2003): A dual isotope approach to identify denitrification in ground water at a river bank infiltration site. - Water Research 37: 3070-3078.

[12] Galloway, J. N., Aber, J. D., Erisman, J. W., Seitzinger, S. P., Howarth, R. W., Cowling, E. B., Cosby, B. J. (2003): The Nitrogen Cascade. - Bioscience 53: 341-356.

[13] Gaouzi, F. J. E., Sebilo, M., Ribstein, P., Plagnes, V., Boeckx, P., Xue, D., Derenne, S., Zakeossian, M. (2013): Using $\delta^{15} \mathrm{~N}$ and $\delta^{18} \mathrm{O}$ values to identify sources of nitrate in karstic springs in the Paris basin (France). - Applied Geochemistry 35: 230-43.

[14] Guo, P., Wang, C. (2009): The investigation and evaluation of sewage draining outlets along the Dagu Sewage River in Tianjin, China. - The Monograph of Academic Annual Conference of Chinese Environmental Sciences Association in 2009 4: 203-210 (in Chinese with English abstract).

[15] He, X., Huang, B. (2013): Analysis of the water quality of Haihe River system and pollution control measures. - Safety and Environmental Engineering 20: 28-32 (in Chinese with English abstract).

[16] Hobbie, E. A., Ouimette, A. P. (2009): Controls of nitrogen isotope patterns in soil profiles. - Biogeochemistry 95(2/3): 355-371.

[17] Jin, Z. F., Gong, J. L., Shi, Y. L., Jin, M. T., Li, F. L. (2017): Nitrate source identification and nitrification-denitrification at the sediment-water interface. - Huanjing Kexue 38(4): 1423-1430.

[18] Knöller, K., Vogt, C., Haupt, M., Feisthauer, S., Richnow, H. (2011): Experimental investigation of nitrogen and oxygen isotope fractionation in nitrate and nitrite during denitrification. - Biogeochemistry 103(1/3): 371-384.

[19] Kendall, C., Elliott, E. M., Wankel, S. D. (2007): Tracing Anthropogenic Inputs of Nitrogen to Ecosystems. - In: Michener, R., Lajtha, K. (eds.) Stable Isotopes in Ecology and Environmental Science. Blackwell, Maiden, pp. 375-449.

[20] Lai, X., Guo, F., Liu, J., Shi, B., Chen, S. (2001): Tianjin Dictionary. - Tianjin Academy of Social Sciences Press, Tianjin (in Chinese).

[21] Li, R., Liu, S., Zhang, G., Ren, J., Jing, Z. (2013): Biogeochemistry of nutrients in an estuary affected by human activities: the Wanquan River estuary, eastern Hainan Island, China. - Continental Shelf Research 57(1): 18-31.

[22] Li, S. L., Liu, C. Q., Li, J., Liu, X., Chetelat, B., Wang, B. et al. (2010): Assessment of the sources of nitrate in the Changjiang River, China using a nitrogen and oxygen isotopic approach. - Environmental Science \& Technology 44(5): 1573-1578.

[23] Liu, X., Li, G., Liu, Z., Guo, W., Gao, N. (2010): Water pollution characteristics and assessment of lower reaches in Haihe River basin. - Procedia Environmental Sciences 2(6): 199-206.

[24] Mcilvin, M. R., Casciotti, K. L. (2011): Technical updates to the bacterial method for nitrate isotopic analyses. - Analytical Chemistry 83(5): 1850-1856. 
[25] Mengis, M., Schif, S. L., Harris, M., English, M. C., Aravena, R., Elgood, R. J. et al. (2005): Multiple geochemical and isotopic approaches for assessing ground water $\mathrm{NO}_{3}{ }^{-}$ elimination in a riparian zone. - Groundwater 37(3): 448-457.

[26] Moore, J. W., Semmens, B. X. (2008): Incorporating uncertainty and prior information into stable isotope mixing models. - Ecology Letters 11: 470-480.

[27] Pardo, L. H., Kendall, C., Pett-Ridge, J., Chang, C. C. Y. (2004): Evaluating the source of streamwater nitrate using $\delta^{15} \mathrm{~N}$ and $\delta^{18} \mathrm{O}$ in nitrate in two watersheds in New Hampshire, USA. - Hydrological Processes 18: 2699-2712.

[28] Parnell, A. C., Inger, R., Bearhop, S., Jackson, A. L. (2010): Source partitioning using stable isotopes: coping with too much variation. - PLoS One 5(3): e9672.

[29] Piña-Ochoa, E., Álvarez-Cobelas, M. (2006): Denitrification in aquatic environments: a cross-system analysis. - Biogeochemistry 81: 111-130.

[30] Sebilo, M., Billen, G., Grably, M., Mariotti, A. (2003): Isotopic composition of nitratenitrogen as a marker of riparian and benthic denitrification at the scale of the whole Seine River system. - Biogeochemistry 63: 35-51.

[31] Semmens, B., Ward, E., Parnell, A., Phillips, D., Bearhop, S., Inger, R., et al. (2013): Statistical basis and outputs of stable isotope mixing models: comment on Fry (2013). Marine Ecology Progress Series 490: 285-289.

[32] Shao, X., Deng, X., Yuan, X., Jiang, W. (2010): Identification of potential sensitive areas of non-point source pollution in downstream watershed of Chaobaixin River. Environmental Science Survey 29: 37-41 (in Chinese with English abstract).

[33] Starks, P. J., Fiebrich, C. A., Grimsley, D. L., Garbrecht, J. D., Steiner, J. L., Guzman, J. A., et al. (2014): Upper Washita River experimental watersheds: meteorologic and soil climate measurement networks. - Journal of Environmental Quality 43(4): 1239.

[34] Templer, P. H., Weathers, K. C. (2011): Use of mixed ion exchange resin and the denitrifier method to determine isotopic values of nitrate in atmospheric deposition and canopy throughfall. - Atmospheric Environment 45(11): 2017-2020.

[35] Torrentó, C., Urmeneta, J., Otero, N., Soler, A., Viñas, M., Cama, J. (2011): Enhanced denitrification in groundwater and sediments from a nitrate-contaminated aquifer after addition of pyrite. - Chemical Geology 287(1): 90-101.

[36] Umezawa, Y., Hosono, T., Onodera, S., Siringan, F., Buapeng, S., Delinom, R., Yoshimizu, C., Tayasu, I., Nagata, T., Taniguchi, M. (2008): Sources of nitrate and ammonium contamination in groundwater under developing Asian megacities. - Science of the Total Environment 404: 361-376.

[37] Villnäs, A., Norkko, J., Hietanen, S., Josefson, A., Lukkari, K., Norkko, A. (2013): The role of recurrent disturbances for ecosystem multifunctionality. - Ecology 94: 2275-2287.

[38] Wang, H., Jia, Y. W., Yang, G. Y., Zhou, Z. H., Chou, Y. Q., Niu, C. W., Peng, H. (2013): Comprehensive simulation of binary water cycle and its associated process in Haihe River Basin. - Science Bulletin 58(12): 1064-1077.

[39] Wang, K., Wang, W., Li, Q., Yu, M., Li, P. (2014): Characteristics of changes of groundwater buried depth and influencing factors in Tianjin plain area over past 21 years. - Water Resources Protection 30(3): 45-49 (in Chinese with English abstract).

[40] Wang, L. (2004): A discussion on the deep fresh water salinization in the plain region of Tianjin City. - Geological Survey and Research 27: 169-176 (in Chinese with English abstract).

[41] Wang, X., Yang, H., Sun, J., Wang, W. (2011): Distribution of nutrients and eutrophication assessment in Tianjin coastal area. - Marine Sciences 35: 56-61 (in Chinese with English abstract).

[42] Wang, Z., Gao, X., Li, M., Pan, J., Yu, C. (2009): Investigation and spatial distribution on nitrate contamination in water of Tianjin. - Journal of Agro-Environment Science 28(3): 592-596 (in Chinese with English abstract).

[43] Wankel, S. D., Kendall, C., Paytan, A. (2015): Using nitrate dual isotopic composition $\left(\delta^{15} \mathrm{~N}\right.$ and $\left.\delta^{18} \mathrm{O}\right)$ as a tool for exploring sources and cycling of nitrate in an estuarine 
system: Elkhorn Slough, California. - Journal of Geophysical Research Biogeosciences 114(G1): 315-327.

[44] Xue, D., Botte, J., Baets, B. D., Accoe, F., Nestler, A., Taylor, P., Van, Cleemput, O., Berglund, M., Boeckx, P. (2009): Present limitations and future prospects of stable isotope methods for nitrate source identification in surface- and groundwater. - Water Research 43: 1159-1179.

[45] Xue, D., Baets, B. D., Vermeulen, J., Botte, J., Cleemput, O. V., Boeckx, P. (2010): Error assessment of nitrogen and oxygen isotope ratios of nitrate as determined via the bacterial denitrification method. - Rapid Communications in Mass Spectrometry 24: 1979-1984.

[46] Xue, D., Baets, B. D., Cleempu, O. V., Hennessy, C., Berglund, M., Boeckx, P. (2012): Use of a Bayesian isotope mixing model to estimate proportional contributions of multiple nitrate sources in surface water. - Environmental Pollution 161: 43-49.

[47] Yang, B., Hui, W., Jiang, Y., Fang, D., He, X., Lai, X. (2018): Combing $\delta^{15} \mathrm{~N}$ and $\delta^{18} \mathrm{O}$ to identify the distribution and the potential sources of nitrate in human-impacted watersheds, Shandong, China. - RSC Advances 8(41): 23199-23205.

[48] Yang, L., Han, J., Xue, J., Zeng, L., Shi, J., Wu, L., Jiang, Y. (2013): Nitrate source apportionment in a subtropical watershed using Bayesian model. - Science of the Total Environment 463-464: 340-347.

[49] Yao, L., Li, G., Tu, S., Gavin, S., He, Z. (2007): Salinity of animal manure and potential risk of secondary soil salinization through successive manure application. - Science of the Total Environment 383: 106-114.

[50] Yue, F., Liu, X., Li, J., Zhu, Z., Wang, Z. (2010): Using nitrogen isotopic approach to identify nitrate sources in waters of Tianjin, China. - Bulletin of Environmental Contamination and Toxicology 85: 562-56. 